\begin{tabular}{|c|c|c|c|c|c|c|}
\hline \multirow{4}{*}{ Impact Factor: } & ISRA (India) & $=3.117$ & SIS (USA) & $=0.912$ & ICV (Poland) & $=6.630$ \\
\hline & ISI (Dubai, UAI & $=0.829$ & РИНЦ (Russia) & $=0.156$ & PIF (India) & $=1.940$ \\
\hline & GIF (Australia) & $=0.564$ & ESJI (KZ) & $=8.716$ & IBI (India) & $=4.260$ \\
\hline & JIF & $=1.500$ & SJIF (Morocco) & $=5.667$ & OAJI (USA) & $=0.350$ \\
\hline
\end{tabular}

\section{SOI: 1.1/TAS DOI: 10.15863/TAS International Scientific Journal Theoretical \& Applied Science}

p-ISSN: 2308-4944 (print) e-ISSN: 2409-0085 (online)

Year: 2019 Issue: $06 \quad$ Volume: 74

Published: $24.06 .2019 \quad \underline{\text { http://T-Science.org }}$
QR - Issue
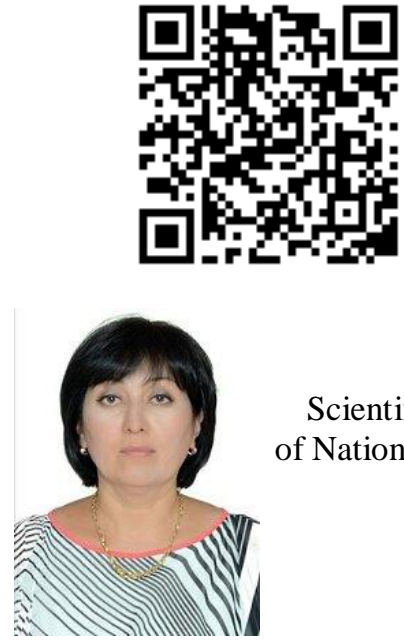

QR - Article

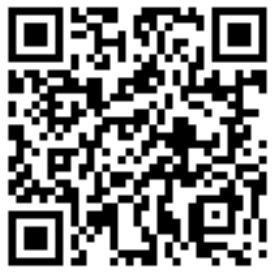

Nasiba Azizova

Karshi State University Scientific researcher, the Department of National Ideas, Basics of Spirituality and Law, Karshi, Uzbekistan +99 (891) 4562683 azizovanasiba@mail.ru

\title{
DEVELOPMENT OF BILINGUALISM IN THE PERIOD NATIONAL INDEPENDENCE OF UZBEKISTAN
}

\begin{abstract}
This article examines the theory of bilingualism: types of bilingualism, the causes of bilingualism and development of national-Uzbek bilingualism in the context of the national independence of Uzbekistan. According to the author, development of bilingualism in various forms is an important factor in strengthening national consolidation, enhancing the economy and culture of Uzbekistan. The author analyzes the theoretical, historical and socio-political aspects of development of bilingualism.

Key words: bilingualism, types of bilingualism, social sources of bilingualism, Uzbekistan, multinational state, national-Uzbek bilingualism, influence of bilingualism on thinking.

Language: English

Citation: Azizova, N. (2019). Development of bilingualism in the period national independence of Uzbekistan. ISJ Theoretical \& Applied Science, 06 (74), 388-391.

Soi: http://s-o-i.org/1.1/TAS-06-74-49 Doi: crossef https://dx.doi.org/10.15863/TAS.2019.06.74.49

\section{Introduction}

Bilingualism is a very complex phenomenon that is comprehensively studied in such disciplines as philosophy, linguistics, psychology. Numerous studies and scientific works of well-known foreign scientists, such as L.Scherba, G.Vereshagin, U. Weinreich, V.Avrorina, and A.Zalevskaya are devoted to the problem of bilingualism. But many of them have different, contradictory opinions that it is important to study, systematizing them. Among them, the problem of the correlation of cultures in the formation of culture of bilingualism has been studied very little.

Bilingualism - a common phenomenon in modern society, associated with the movement of ethnic, political, geographical factors. The intensity of international relations, the free movement of capital and labor, information, cultural and political integration require knowledge of two or more languages. This is important for obtaining education, work or activities in another country [1, p.89]. In the current period, when the mixture of peoples, languages and cultures has reached unprecedented scope, and more than ever the problem of raising

tolerance for foreign cultures, awakening interest and respect for others, bilingualism in intercultural communication acquires extraordinary importance.

The term bilingualism from Latin means "bi" two, and "linqua" - language. In special literature, the concept of bilingualism has many definitions. Combining these definitions, bilingualism means the simultaneous use of two languages. For example, if $U$. Weinreich calls "bilingual practice the alternate use of two languages" [2, p.48], then Rosenzweyg defines "Bilingualism is usually understood as the possession of two languages, regular switching from one to another depending on the situation of communication" [3, p.67]. The commonality of data definitions by linguists is that the simultaneous free use of languages is not focused on how widely used is the second language, but on the practical use of communication.

Scientists distinguish different types of bilingualism: individual and social bilingualism (for example, in countries with two state languages). For example, E.M. Vereshagin distinguishes three levels of bilingualism: receptive (a type of bilingualism in which an individual who speaks a second language understands it, although he cannot synthesize text in a given language), reproductive (an individual can
\end{abstract}




\begin{tabular}{|c|c|c|c|c|c|c|}
\hline \multirow{4}{*}{ Impact Factor: } & ISRA (India) & $=3.117$ & SIS (USA) & $=0.912$ & ICV (Poland) & $=6.630$ \\
\hline & ISI (Dubai, UAI & $=0.829$ & РИНЦ (Russia & $=0.156$ & PIF (India) & $=1.940$ \\
\hline & GIF (Australia) & $=0.564$ & ESJI (KZ) & $=8.716$ & IBI (India) & $=4.260$ \\
\hline & JIF & $=1.500$ & SJIF (Morocco & $=5.667$ & OAJI (USA) & $=0.350$ \\
\hline
\end{tabular}

reproduce what he read and heard in that language on which he perceived them) and productive (the ability not only to understand and reproduce, but "to make up meaningful statements") [4, p.112].

In the theory of bilingualism the causes of the emergence of bi - and polingvism, that is, social sources are studied [5, p. 98]. Various contacts:

a) the mixed coexistence of different nationalities on the same territory. In the same city can live a few dozen or hundreds of different nationalities who have not forgotten their native language. In neighboring regions, near the borders, the number of people speaking two languages is growing. In some countries (Switzerland, Canada) the people who can communicate freely in two or three languages make up a large number. There are also countries in which linguistic inequalities can be traced, which sometimes leads to serious conflicts. However, despite the conflicts, bilingualism also inevitably develops;

b) there is an increase in bilingualism as a result of political conflicts, wars and labor migration;

c) economic, commercial and cultural ties, education, tourism and other social ties and factors lead to the study of other languages;

d) in the education system, foreign languages are studied (independently in families) in secondary schools and higher educational institutions of all countries;

In general, knowledge of languages spiritually enriches a person, develops intelligence, expands educational opportunities, gives him the opportunity to read foreign literature, scientific works, travel around the world and communicate with people without an interpreter.

\section{Materials and Methods}

Uzbekistan is known as a multinational state. Uzbek as a state language should serve as a means of inter-ethnic interaction, to unite and consolidate the peoples of the republic.

It should be especially noted that the multinationality of our country was complicated by the influence of socio-political factors. In particular, during the times of the tsarist invasion and the Soviet empire, representatives of different nationalities moved to our country. Also, the national composition of our republic changed again during the Second World War (1941-1945). Uzbekistan received more than 1 million evacuees from the front lines, helped them and showed kindness. In addition, as a result of repressions of all people's, representatives of different nations, such as Koreans, Crimean Tatars, Meskhetian Turks, Germans who were forced to move to our country, were obligatory resettled in our country. If in 1897, representatives of 70 different nationalities lived on the territory of Uzbekistan, then in 1926 their number reached 91, in 1959 it was 113, and in 1979 it was 123 . Today, their number is more than 130 , the share of the population of Uzbekistan is 20 percent [6, p.616].

Analysis of the results of a study conducted by the Institute of Strategic and Regional Studies under the President of the Republic of Uzbekistan showed that among the representatives of other nationalities living in our country, namely the Slavic diaspora (Russians, Ukrainians, Belarusians) - 38.6\%, the people of Volgograd (Tatars, Bashkirs, Chuvash) $72.5 \%$, the people of Central Asia (Kazakhs, Tajiks, Kyrgyz, Turkmen) - 78.2\% consider Uzbekistan to be their birthplace. All of them are bilingual at one level or another: they know both Uzbek and native. This form of bilingualism is called national-Uzbek bilingualism. In addition, Uzbek-Tajik, UzbekKazakh, Uzbek-Kyrgyz, Uzbek-Russian bilingualism is quite common among Uzbeks throughout Samarkand, Bukhara, and some areas.

Giving the Uzbek language the status of the state language has become a great impetus for the development of national-Uzbek bilingualism. Representatives of other nationalities who consider Uzbekistan their homeland, increased attention to the study of the Uzbek language. The number of families who send their children to Uzbek schools has increased noticeably.

The multinational development of Uzbekistan also requires the development of national-Uzbek bilingualism. This is necessary so that representatives of other nations and nationalities living in Uzbekistan could integrate more deeply into society, contribute to the development of our country as a whole, fully realize their capabilities. Whatever state it is, it will not be able to achieve progress without bilingualism. The reason is that bilingualism is one of the most effective means of achieving the world achievements of science and culture. Around the world, several hundred thousand special translators are needed for the translation of scientific, technical news and other information in time. If we spend our intellectual potential only on translation, the number of people who are directly involved in creative work will reduce. Therefore, every specialist, especially the creative intelligentsia, without translation should read and understand the literature relating to his field in English, Russian, French, German.

The history and current state of our Uzbek culture is largely associated with bilingualism. At their own time, such scholars as Al-Farabi, Abu Rayhan Beruni, Ibn Sina, Ulugbek, Ali Kushchi, AlBukhari, Al-Termizi, Khoja Bahauddin Naqshband, Navoi, Babur, studied Arabic and Persian, and some even Sanskrit, Greek and Latin, they became geniuses of their time for careful study and development of scientific, artistic, philosophical works created in these languages. Therefore, it was not for nothing that scientists said that this was the era of the "Eastern Renaissance." By knowing many languages, they became acquainted with the socio-economic 


\begin{tabular}{|c|c|c|c|c|c|c|}
\hline \multirow{4}{*}{ Impact Factor: } & ISRA (India) & $=3.117$ & SIS (USA) & $=0.912$ & ICV (Poland) & $=6.630$ \\
\hline & ISI (Dubai, UAI & $=0.829$ & РИНЦ (Russia & $=0.156$ & PIF (India) & $=1.940$ \\
\hline & GIF (Australia) & $=0.564$ & ESJI (KZ) & $=8.716$ & IBI (India) & $=4.260$ \\
\hline & JIF & $=1.500$ & SJIF (Morocco & $=5.667$ & OAJI (USA) & $=0.350$ \\
\hline
\end{tabular}

development and culture of other countries and, thanks to their works, they introduced our country to the whole world by their masterpieces.

There is no consensus among scientists on how bilingualism affects thinking. In particular, the need to learn languages from childhood and the perception of what is done in practice, how does the growing child's consciousness affect, does confusion cause? Some philosophers and psychologists positively assess the impact of bilingualism on thinking, while others do not have a significant positive or negative impact. However, in practice, all three situations may arise. It depends on the teaching methods and level of instruction in the language. Bilingualism does not have a negative impact on thinking with the best knowledge of one of the languages. Comparative knowledge of two languages has a positive effect on thinking. As noted above, the problem of bilingualism remains one of the controversial problems in science, especially in social psychology and social philosophy. Philosophers, psychologists, representatives of social linguistics dealing with language and thinking, among various groups, linguistic sociologists who study the tendencies of language and culture, note that bilingualism has a negative impact on thinking, that there is a mixture in the speech of the majority of both languages and interference of languages.

The influence of bilingualism can be both positive and negative, depending on the conditions in which the interaction of two languages takes place. W. Lambert (1974) writes about this. He distinguishes between two types of bilingualism: additive bilingualism and subtractive bilingualism. When the first language is the main one and learning a second language does not crowd out the first, bilingualism has a positive cognitive effect. In this case additive bilingualism takes place. In the opposite situation, the impact of bilingualism is negative and is called subtractive bilingualism [7, pp. 71-87].

Considering the issue of the impact of bilingualism, most researchers emphasize the importance of language proficiency [7, pp. 71-87.]. J. Cummins put forward an "interdependence hypothesis". He pointed out that if the child's first language skills and linguistic skills were well developed, the bilinguals would be able to use the skills of a language in the second language and use it successfully, and that the second language would be easily integrated (Cummins, 1991) [8, p. 310].

"Theory of the threshold level" is aimed at determining the causes and patterns of the positive influence of bilingualism on the intellectual development of the individual. It focuses on a certain point from which the positive influence of bilingualism on the cognitive abilities of a person. According to this theory, a bilingual child must reach certain thresholds in his development in order to have a positive impact of bilingualism (Cummins, 1979; Skutnabb-Kangas \& Toukomma, 1976). Researchers identify two threshold levels - the lower (lower threshold) and upper (upper threshold). The achievement of the lower level occurs when oral speech development in the native language can continue its development along with the second language without any interference from its side. Achieving this level helps to avoid the negative effects of bilingualism. Reaching the upper level implies a positive impact and is associated with the development of reading skills (Cummins, 1979) [9, p.404].

Those who are in the opposite opinion emphasize that bilingualism has only a positive effect on thinking. Another group of scientists, being indifferent to the position, insists that bilingualism does not have a positive or negative impact on thinking. All these views are one-sided. In fact, any of the above cases can occur under certain conditions.

\section{Conclusion}

In conclusion, it can be said that the development of bilingualism in various forms is an important factor in strengthening national consolidation and improvement of the economy and culture of Uzbekistan. In this regard, the necessary conditions must be created for the national-Uzbek bilingualism, that is, other people living in Uzbekistan, along with their native language, know the Uzbek language. This also follows from the law of Uzbekistan "On the state language" and directly depends on the fate of the future of the country. National-Uzbek bilingualism should be implemented voluntarily through sciencebased policies, while national languages should not contradict each other, but complement each other freely.

\section{References:}

1. Triarchi-Herrmann, V. (2003). Mehrsprachige Erziehung / Wie Sie Ihr Kihd fodern / V. Triarchi-Herrmann. (p.89). Munchen Ernst Reinhardt Verlag.
2. Weinreich, U. (1979). Yazikoviye kontakti. (p.48). Kiev.

3. Rosenzweig, V. Y. (1972). Osnovniye voprosi yazikovich contactov // Novoye v lingvistice. Yazikoviye contacti. (p.67). Moscow. 


\begin{tabular}{|c|c|c|c|c|c|c|}
\hline \multirow{4}{*}{ Impact Factor: } & ISRA (India) & $=3.117$ & SIS (USA) & $=0.912$ & ICV (Poland) & $=6.630$ \\
\hline & ISI (Dubai, UAE & $=0.829$ & РИНЦ (Russia & $=0.156$ & PIF (India) & $=1.940$ \\
\hline & GIF (Australia) & $=0.564$ & ESJI (KZ) & $=8.716$ & IBI (India) & $=4.260$ \\
\hline & JIF & $=1.500$ & SJIF (Morocce & $=5.667$ & OAJI (USA) & $=0.350$ \\
\hline
\end{tabular}

4. Vereshchagin, G. M. (1969). Psychologicheskaya $i$ methodologicicheskaya characteristica bilingualisma. (p.112). Moscow: Publishing House of Moscow State University.

5. Lvov, M. R. (2002). Osnovi theoriya rechi: Textbook. allowance for stud. higher ped. studies. institutions. (p.98). Moscow: Publishing Center "Academy".

6. (2005). Uzbekistan na puti demokratizatsii i obnovleniya obshestva, modernizatsii i reformirovaniya strani. (p.616). Ie: Academy.
7. Cenoz, J. (2003, March). The additive effect of bilingualism on third language acquisition: a review [Text]. International Journal of Bilingualism, Vol. 7, No. 1, pp.71-87.

8. Gonzalez, V. (1999). Language and Cognitive Development in Second Language Learning: Educational Implications for Children and Adults [Text]. (p.301). Boston, MA: Allyn and Bacon.

9. Skutnabb-Kangas, T. (1983). Bilingualism or not: The education of minorities [Text]. (p.404). Clevedon: Multilingual Matters. 
ISRA (India) $\quad \mathbf{=} \mathbf{3 . 1 1 7}$

Impact Factor: $\quad$ ISI (Dubai, UAE) $=\mathbf{0 . 8 2 9}$

GIF (Australia) $=\mathbf{0 . 5 6 4}$

JIF

$=1.500$
SIS (USA)

РИНЦ $($ Russia $)=0.156$

$\mathrm{ESJI}(\mathrm{KZ}) \quad=\mathbf{8 . 7 1 6}$

SJIF $($ Morocco $)=\mathbf{5 . 6 6 7}$
ICV (Poland)

PIF (India)

IBI (India)

$=6.630$ 